УДК 378.046.4:004

DOI: $10.24061 / 2413-4260 . X I .3 .41 .2021 .2$

\section{I. Редько}

Державний заклад «Запорізька медична академія післядипломної освіти Міністерства охорони здоров'я України»

(м. Запоріжжя, Україна)
ОСОБЛИВОСТІ ВИКОРИСТАННЯ

СУЧАСНИХ ІННОВАЦІЙНИХ ТЕХНОЛОГІЙ У ПІСЛЯДИПЛОМНІЙ OCBITI

Резюме. Проблема якості вищої медичної освіти в Україні завжди посідала одне з перших місиь у загальноначіональному рейтингу. Оскільки удосконалення якості навчання є актуальною проблемою в системі післядипломної освіти, сучасний підхід до процесу навчання лікарів-фахівців на курсах підвищення кваліфікації та лікарів-інтернів повинен включати впровадження нових освітніх (педагогічних, інформаційних та телекомунікаційних) технологій. В умовах пандемії корона вірусної інфекиії COVID-19 усім вищим медичним закладам доводиться все більше змінювати загальноприйняті та перевірені часом і досвідом підходи до надання якісноі освіти лікарям та впроваджувати у навчальний процес сучасні новітні технології. Зазначені у статті досвід та аналіз особливостей впровадження сучасних інноваційних технологій на післядипломному етапі освіти допоможуть суттєво покращити результативність засвоєння як теоретичної, так $і$ практичної частини підготовки по кожній лікарській спеціальності.

Ключові слова: інноваційні методи навчання, післядипломна освіта, лікарі-фахівці, лікарі-інтерни.

\section{Вступ}

Запровадження нової моделі безперервного професійного розвитку лікаря на післядипломному етапі є важливою складовою модернізації освітнього простору, що сприяє постійному професійному розвитку лікаря через вдосконалення його компетенцій [1-3]. При цьому, подальше реформування системи освіти можливе при всебічному доступі до освітніх і професійних ресурсів усіх учасників навчального процесу. Інформатизація суспільства та впровадження інноваційних підходів до освітнього процесу створили умови для створення навчальних курсів 3 елементами дистанційного навчання. Технологія змішаного навчання, при якій навчання проводиться як в традиційній очній формі, так і з використанням інформаційно-освітніх технологій, зокрема дистанційного навчання, повною мірою відповідає поставленим вимогам сьогодення $[1,5]$. Змішана освітня система дозволяє виробити якісні навички лікарських дій, безперервно підтримувати професійні знання та вміння на високому рівні, мотивувати лікарів до безперервного підвищення професійної компетенції. Нинішній час $є$ особливим, так як пандемія COVID 19 прискорює застосування інновацій у освіті для того, щоб зберегти в обмежених умовах любов до професії та інтерес до освіти. Тому впровадження елементів інноваційних технологій у навчальний процес займає особливе місце.[3-5]

Згідно з постановами Кабінету Міністрів України, Міністерства охорони здоров'я України про засоби щодо запобігання поширення коронавірусної інфекції COVID 19 та інших нормативноправових актів, регулюючих запровадження та посилення карантинних обмежень, вищі медичні заклади були переведені з березня 2020 року на дистанційну форму навчання, а 3 вересня 2020 року - на змішану форму навчання (50\% дистанційного та $50 \%$ очного навчання) з використанням технологій дистанційного навчання.

Мета статті - дослідити досвід та провести аналіз впровадження сучасних інноваційних методів для поліпшення якості навчання лікарів на післядипломному етапі.

\section{Матеріали та методи}

Досвід роботи курсу амбулаторної педіатрії в складі кафедри педіатрії та неонатології Д3 «ЗМАПО МОЗ України» складає 7 років. Проаналізовано якість викладання дисципліни «Педіатрія» на циклі інтернатури за фахом «Загальна практика-сімейна медицина» та на циклі «Спеціалізація» для лікарів за фахом «Загальна практика-сімейна медицина». Для оцінювання результативності та якості отриманих знань, а також для визначення перспектив використання дистанційного навчання були створені анкети для лікарівінтернів та слухачів, яким викладався розділ «Педіатрія» в рамках існуючих циклів. В анкетуванні взяло участь 206 респондентів, 3 яких 78 - лікаріінтерни, 128 - лікарі-слухачі циклу «Спеціалізація». Анкетування проводили до карантинних обмежень та в період карантину.

\section{Результати та їх обговорення}

Організація навчального процесу для лікарівінтернів за фахом «Загальна практика-сімейна медицина» враховувала наступні особливості: усі лікарі-інтерни були випускниками вищих медичних закладів за спеціальностями «Лікарська справа» - 59,8\% лікарів, «Педіатрія»-40,2\% лікарів. Якість додипломної підготовки лікарів-інтернів за дисципліною «педіатрія» відрізняється 3 урахуванням як спеціальності лікаря, так і медичного вузу, який закінчив лікар. Додипломна підготовка лікарів-інтернів за дисципліною «педіатрія» за даними базисного письмового контролю знань показала, що позитивні відповіді на тестові завдання спостерігалися у $43,3 \%$.

Організація навчального процесу для лікарівслухачів циклу «Спеціалізація» за фахом загальна практика-сімейна медицина також мала особливості, так як 85\% були за спеціальністю лікарями-терапевтами. Тому позитивні відповіді на тестові завдання базисного контролю спостерігали лише у $35 \%$ респондентів.

Результати анкетування до карантинних обмежень засвідчили, що удосконалення практичних навичок із застосуванням симуляторів навчання 
або біля ліжка хворого потребують лікарі-інтерни та лікарі-слухачі - біля 92,1\%; самостійної курації пацієнтів та складання плану діагностики та лікування 3 наступним розбором в групі $-73,7 \%$; проведення інтерактивних занять $-89,5 \%$; поглибленого вивчення невідкладних станів з чітким алгоритмом надання лікарської допомоги $-100 \%$; впровадження комп'ютерних технологій (презентації, відеоконференції) для поліпшення сприйняття матеріалу по дисципліни $-100 \%$; проведення клінічних розборів та конференцій з актуальних питань педіатрії $-94,7 \%$; отримання на кафедрі сучасних стандартів -93\%.

У період карантину реалізація освітнього процесу проводилась із застосуванням технологій дистанційного навчання 3 використанням системи Moodle та платформи Google Meet. При опитуванні щодо якості навчання в період карантину 75\% респондентів відмітили, що якість знань, які викладались за допомогою технологій дистанційного навчання, у цілому залишалась на попередньому рівні викладання в очній формі, яка застосовувалась до карантинних обмежень. Відношення до дистанційної форми навчання як позитивного було відзначено у $87 \%$ респондентів, $89 \%$ - надають перевагу змішаній формі навчання, відмічаючи важливість безпосередньої комунікації з викладачем та по між собою для збереження отриманих знань та підвищення якості освіти. Серед позитивних моментів відмічено можливість лікарів бути присутніми на заняттях незалежно від місця знаходження - 93\%, можливість виконувати індивідуальні завдання та завдання для самостійної роботи у зручному темпі та більш комфортних для себе умовах, що дозволяло використовувати в необхідному обсязі навчальні ресурси та сприяло кращому засвоєнню матеріалу. Значна кількість лікарів (88\%) у якості позитивного моменту дистанційного навчання відмітили можливість постійних контактів усіх учасників учбового процесу за допомогою спеціалізованого інформаційного середовища (електронної пошти, відеозв'язоку, Google календаря та ін.). Серед недоліків 68\% лікарів відмітили не завжди якісний відеозв'язок з викладачем у зв'язку з низьким доступом до швидкісного інтернету на робочому місці, майже $100 \%$ лікарів довелося освоювати нові комп'ютерні програми або платформи для здійснення навчальної діяльності.

При опитування загальне враження від курсу «Педіатрія» оцінили: «відмінно» - 46,4\%, «добре» - 44,4\%, формат онлайн-лекцій оцінили як : «відмінно»- 61,5\%, «добре»-38,5\%, розуміння викладеного лекційного матеріалу оцінили: «відмінно» - 58,2\%, «добре»- 41,8\%. Серед недоліків $61 \%$ лікарів відмітили зниження можливості повноцінного дискусійного обговорення ситуаційних задач та клінічних випадків з урахуванням технічних особливостей платформ, що використовувались, зниження можливостей оволодіння практичними навичками.

Оцінка проведення навчального процесу викладачами курсу показала, що серед позитивних моментів практично не було відсутніх на заняттях, серед недоліків відмічено необхідність якісного інтернет 3'єднання та обладнання для проведення занять на належному рівні. Також відмічалась під- вищена навантаженість викладачів при підготовці до занять, яка потребувала створення та розробки спеціальних навчально-методичних матеріалів та презентацій для кращого сприйняття матеріалу.

Відомо, що ефективність засвоєння знань залежить не лише від методів і прийомів навчання, але й від форм організації навчального процесу. Сучасний рівень розвитку післядипломної освіти орієнтує викладача на перехід від традиційного викладання матеріалу до впровадження нових інтерактивних технологій при проведенні лекцій, семінарських та практичних занять. У післядипломній освіті однієї тільки теоретичної підготовки для лікарів-інтернів не достатньо, володіння практичними навиками має також дуже велике значення. Саме тому викладачами кафедри була удосконалена теоретична та практична частина учбового процесу для лікарів за фахом «загальна практикасімейна медицина» за дисципліною «педіатрія». Процес оптимізації навчання був направлений на підвищення мотивації оволодіння спеціальністю.

Використання прогресивних методів навчання, зокрема, комп'ютерних навчальних технологій, розширили можливості для більш якісної підготовки лікарів. На кафедрі використовується презентаційний лекційний матеріал, на практичних заняттях і семінарах застосовуються наявні навчальні програми, методичні вказівки до проведення практичних та семінарських занять, а також відеофільми по актуальним питанням педіатрії та неонатології. Для закріплення знань, отриманих на лекціях, застосовуються етапні контрольні роботи як один із методів позааудиторної підготовки, а також тестовий контроль за кожною темою. Підготовлені набори тестових завдань та ситуаційні задачі для практичних та семінарських занять, які дозволяють контролювати знання впродовж циклу.

3 метою формування здібностей до самостійної лікарської діяльності застосовано різні види практичних занять. Найбільш ефективними методами навчання лікарів-інтернів є використання інноваційних методів занять виявилися: інтерактивні семінари, круглі столи та інтерактивні ігри, які дозволяють моделювати різноманітні клінічні ситуації, наближені до реальних умов, 3 обов'язковим динамічним розвитком завдань, що вирішуються. За результатами анкетування доведено, що 95,2\% лікарів позитивно оцінили використання інтерактивних методів навчання та відзначили доцільність їх використання у післядипломній освіті. Згідно з результатами обговорення з викладачами, зазначені методи навчання підвищили ступінь самостійної підготовки до занять і активності лікарів під час їх проведення, мотивацію до навчання, сприяли розвитку клінічного мислення, тренували вміння обгрунтовувати власну позицію в професійній сфері.

У світових напрямках розвитку післядипломної освіти чітко проявляється тенденція зростання частки самостійної роботи і зміщення акценту з викладання на навчання [6-7]. Самостійна робота в сучасному освітньому полі розглядається як форма організації навчання, яка здатна забезпечувати самостійний пошук необхідної інформації 3 використанням принципів доказової медицини, 
сприйняття і осмислення навчального матеріалу в ході аудиторних занять і в позааудиторний час, розвиток аналітичних здібностей, навичок контролю і планування навчального часу. Згідно з вимогами нормативних документів самостійна робота $\epsilon$ обов'язковим компонентом освітнього процесу. На кафедрі самостійна робота лікарів-інтернів та лікарів-слухачів виконується без участі викладача, але за його завданням і керівництвом, що є однією $з$ форм організації навчального процесу. До самостійної роботи відносяться різні за формою і організацією заняття, що відображають види діяльності лікаря: робота 3 навчальними посібниками і літературою, робота у вигляді навчальних завдань зі складанням алгоритму обстеження пацієнтів, вправи з тестовими і ситуаційними завданнями, підготовка рефератів.

Одним з результатів самостійної роботи є написання рефератів 3 мультимедійною демонстрацією і наступною усною доповіддю перед аудиторією, а також обов'язковим обговоренням і оцінкою представленої роботи. Реферати зберігаються в архіві та складають тематичне портфоліо. Практика показує, що лікарі розрізняються за рівнем готовності до реалізації вимог до самостійної роботи. Більшість лікарів мають високу мотивацію та успішно дотримуються вимог до виконання реферативної роботи. Поодинокі випадки низького рівня навичок лікаря до самоорганізації дає можливість викладачу використовувати індивідуальний підхід (доповідь реферату на занятті в групі).

Головною метою самостійної роботи лікарів $\epsilon$ формування системи знань, вмінь та навичок, які вони можуть вільно та самостійно застосовувати у своїй практичній діяльності. 3 нашої точки зору, найбільш адекватним є дистанційні освітні технології, які передбачають використання цифрових носіїв інформації (електронні навчальні посібники, презентації лекцій, перегляд відеофільмів, робота 3 довідниками, базами даних, ознайомлення з наказами MO3 України, законодавчою базою). При цьому наш досвід показує, що на сьогоднішній день лише поєднання прямого спілкування 3 дистанційними формами різного характеру, а також наявність у лікарів індивідуальної мотивації здатне забезпечити якісний результат післядипломної освіти.

Застосування сучасних комп'ютерних технологій навчання, відеотехніки може бути найбільш успішно реалізовано тільки в комплексі із застосуванням друкованих носіїв інформації у поєднанні з професіоналізмом викладача [2-3]. Зокрема, викладач післядипломної освіти має володіти в повному обсязі всіма практичними навичками у своїй спеціальності, бути не тільки майстром теоретичної підготовки, а й професіоналом високого класу. Адже авторитет такого викладача, бажання вчитись у нього, підвищувати свою професійну майстерність не викликає жодних сумнівів $[3,5-6]$. Поліпшення якості навчання викладачами курсу направлено на удосконалення практичних навичок по наданню невідкладної допомоги, оволодінню сучасними медичними методиками, правильній інтерпретації лабораторних та інструментальних даних та широке застосування інформаційних технологій.

Одна з основних задач викладання - це навчання лікарів щодо визначення напрямку діагностичного пошуку, проведення диференціальної діагностики, формулювання заключного діагнозу з призначенням лікування та програми реабілітації. Задача лікаря - вміти оцінити тяжкість стану пацієнта, виділити особливості клінічного перебігу хвороби та їі розвитку, аналізувати вплив супутніх захворювань на стан дитини, формулювати основний діагноз, що визначає подальшу лікувальну тактику та правильний вибір медикаментозної терапії.

Сучасна медична освіта повинна поєднувати традиційні засоби оволодіння практичними навичками та симуляційні методи навчання з використанням муляжів, фантомів, тренажерів. Нині не можна говорити про забезпечення належного рівня кваліфікації лікарів без створення й підтримання можливостей доступу до тренінгових центрів 3 широким набором симуляторів, віртуальних засобів, які дозволяють заглиблюватись у будь-яку клінічну ситуацію і успішно їі вирішувати [6-7]. Такий інноваційний підхід дозволяє викладачам моделювати клінічні ситуації, безпечні для пацієнта, забезпечувати контроль та об'єктивну оцінку знань лікарів. Для лікарів - це можливість багаторазового повторення дій для закріплення вміння розпізнавати та своєчасно ліквідувати власні помилки, професійно оволодіти медичними маніпуляціями. Наявність в ДЗ «ЗМАПО МОЗ України» симуляційного класу з багатофункціональними технологічними засобами для навчання дає можливість удосконалити практичні навички лікарів для подальшої практичної роботи. Це дозволяє, з одного боку, індивідуалізувати викладацький підхід, з іншого - більш оперативно висвітлювати безперервно виникаючі актуальні питання відповідно до сучасних стандартів лікування. Лікарі нашого курсу мають змогу удосконалювати практичні навички по наданню невідкладної допомоги пацієнтам на базі симуляційного тренінгового центру. Практичне заняття на манекені - це поглиблене вивчення розділу невідкладних станів, протоколів діагностики, реанімації та інтенсивної терапії пацієнтів, які перебувають у критичному стані.

Таким чином, сучасна медична освіти повинна поєднувати традиційні способи оволодіння практичними навичками та симуляційні методи навчання 3 використанням муляжів, фантомів, тренажерів.

Особливу увагу потребує навчання лікарів вмінню дотримуватися правил етики і деонтології, індивідуальному психологічному підходу до пацієнта.

Післядипломна освіта лікарів в Україні має забезпечуватись визнанням підвищення професійного рівня лікарів не тільки на заходах, що організовуються кафедрами післядипломної освіти, але й на спеціалізованих курсах, стажуванні за кордоном, онлайн-курсах, конференціях, симпозіумах і конгресах вітчизняного та міжнародного рівня, організаторами яких є профільні громадські асоціації [2-3].

\section{Висновки}

1. Приймаючи до уваги умови надання та отримання освітніх послуг в період карантинних обмежень, використання технологій дистанційного на- 
вчання дозволяє лікарям на післядипломному етапі засвоїти навчальну програму з педіатрії в повному обсязі незалежно від місця знаходження здобувача.

2. 3 метою підвищення якості післядипломної освіти перевагу, за можливістю, доцільно нада- вати змішаній формі навчання. Дистанційне навчання не може замінити проведення практичних занять безпосередньо у клініці та засвоєння лікарями практичних навичок обстеження хворого та надання невідкладної допомоги.

\section{Література}

1. Барміна Г. Стан та перспективи медичної освіти в Україні. Аптека.иа [Інтернет]. 2017 [цитовано 2018 Лис 27];6. Доступно: https://www.apteka.ua/article/401518

2. Дистанційна освіта [Електронний ресурс] - Режим доступу: https://mon.gov.ua/ua/osvita/visha-osvita/distancijna-osvita

3. Про організаційні заходи для запобігання поширенню коронавірусу COVID-19. Наказ МОН України №406 від 16.03.2020 [Інтернет]. Київ: МОН України; 2020[оновлено 2020 Кві 8; цитовано 2021 Лип 18]. Доступно: https:/ zakon.rada.gov.ua/rada/show/v0406729-20\#Text

4. Павленко ОО. Використання дистанційного навчання у вищих навчальних закладах. Вісник Національного технічного університету України «Київський політехнічний інститут». 2007;1(3):78-85.

5. Народження нової освітньої моделі для розвитку лікарів. Дайджест матеріалів спеціалізованих професійних медичних видань [Інтернет]. 2018 [цитовано 2021 Tра 27];2. Доступно: https://accemedin.com/img/content/materials/ images/digest 2.pdf Симуляційне навчання як концепція і метод. Дайджест матеріалів спеціалізованих професійних медичних видань [Інтернет]. 2018 [цитовано 2018 Лис 27];2:14-7. Доступно: https://accemedin.com/img/content/ materials/images/digest_2.pdf

6. Стечак ГМ. Педагогічна підготовка майбутніх сімейних лікарів у медичному університеті [дисертація]. Львів; 2017. 282c.

\section{ОСОБЕННОСТИ ИСПОЛЬЗОВАНИЯ СОВРЕМЕННЫХ ИННОВАЦИОННЫХ ТЕХНОЛОГИЙ В ПОСЛЕДИПЛОМНОМ ОБРАЗОВАНИИ}

\section{И.И. Редько}

ГЗ «Запорожская медицинская академия последипломного образования МЗ Украины» (г. Запорожье, Украина)

Резюме. Проблема качества высшего образования в Украине всегда занимала одно из первых мест в общенациональном рейтинге. Поскольку усовершенствование качества обучения является актуальной проблемой в системе последипломного образования, современный подход к процессу обучения врачейслушателей на курсах повышения квалификации и врачей-интернов должен включать внедрение новых образовательных (педагогических, информационных и телекоммуникационных) технологий. В условиях пандемии коронавирусной инфекции COVID-19 всем высшим медицинским учереждениям приходится все больше менять общепринятые и проверенные временем и опытом подходы к организации качественного образования врачей и внедрять в учебный процесс современные инновационные технологии. Представленные в статье опыт и анализ особенностей внедрения использования современных инновационных технологий на последипломном этапе образования помогут существенно улучшить результативность усвоения как теоретической, так и практической части подготовки по любой врачебной специальности.

Ключевые слова: инновационные методы обучения; последипломное образование; врачи-интерны; врачи-слушатели.

\section{Контактна інформація:}

Редько Ірина Іванівна - д.мед.н., професор, професор кафедри педіатрії та неонатології з курсом амбулаторної педіатрії ДЗ «Запорізька медична академія післядиппомної освіти МОЗ України», М. Запоріжжя, Україна

e-mail: redkoirina61@gmail.com

ORCID: http://orcid.org/0000-0001-81657036

\section{Контактная информация:}

Редько Ирина Ивановна - д.мед.н., профессор, профессор кафедры педиатрии и неонатологии с курсом амбулаторной педиатрии ГУ «Запорожская медицинская академия последипломного образования М3 Украины», г.. Запорожье, Украина e-mail: redkoirina61@gmail.com ORCID: http://orcid.org/0000-00018165-7036

\section{FEATURES OF USING MODERN INNOVATIVE TECHNOLOGIES IN POSTGRADUATE EDUCATION}

\section{I. Redko}

State Health Center «Zaporozhye Medical Academy of Postgraduate Education of the Ministry of Health of Ukraine»

(Zaporozhy, Ukraine)

Summary. The problem of the quality of higher education in Ukraine has always occupied one of the first places in the national rating. Since the improvement of the quality of training is an urgent problem in the system of postgraduate education, a modern approach to the process of training doctors-students in advanced training courses and doctors-interns should include the introduction of new educational (pedagogical, information and telecommunication) technologies. In the context of the COVID-19 coronavirus infection pandemic, all higher medical institutions have to increasingly change the generally accepted and time-tested approaches to providing quality education to doctors and introduce modern innovative technologies into the educational process. The experience and analysis of the features of the introduction of modern innovative technologies at the postgraduate stage of education presented in the article will help to significantly improve the effectiveness of mastering both the theoretical and practical part of training in each medical pecialty.

Keywords: Innovative Teaching Methods; Postgraduate Education; Doctors-Interns; DoctorsStudents.

\section{Contact Information:}

Iryna Redko - MD, Professor, Professor of the Department of Pediatrics and Neonatology with the course of outpatient pediatrics State Institute "Zaporizhzhia Medical Academy of Postgraduate Education of Ministry of Health of Ukraine" (Zaporozhye, Ukraine) e-mail: redkoirina61@gmail.com ORCID: http://orcid.org/0000-0001-81657036 